\title{
Literature Review of Modern Beijing Aesthetic Culture
}

\author{
Ningning Wang \\ School of Literature \\ Capital Normal University \\ Beijing, China
}

\begin{abstract}
In many books on the study of Beijing culture, the research involving aesthetic culture can be divided into two major categories. The first category is tracing the origin, in which it summarizes the aesthetic characteristics of Beijing culture from the perspective of historical development. The author summarizes the development characteristics of Beijing's aesthetic culture and the academic achievements of aesthetic laws directly from the source of the birth of Beijing culture, while the second category examines the prominent cultural phenomenon and social causes of contemporary Beijing culture from a microscopic point of view. Through the investigation of urban changes, the author intends to seek the complex relationship between tradition and modernity.
\end{abstract}

Keywords-mordern; Beijing aesthetic culture; research review; urban culture research

\section{INTRODUCTION}

Urban cultural research is a very big topic and can be divided into different sub-topics to facilitate the research. To study urban culture from the perspective of aesthetics, we should first clarify the scope and boundaries of the research. Through sorting out document literature of aesthetic cultural studies, it can be seen that aesthetic culture not only includes artistic creation, but also has a high degree of social factors such as material civilization and spiritual civilization. It is even the imprint of social culture. The significance of the research lies in gaining a feeling of a more intrinsic common factor, which comes from life and is higher than life. Aesthetic culture is an experiential one, which includes human subjective consciousness and social existence that gives rise to people's spiritual pleasure. In investigating the aesthetic features of a city, we should pay attention to the influence of aesthetic issues and aesthetic activities of specific times on people living in the city, summarize aesthetic rules, reveal the causes of aesthetic phenomena, and make predictions and prospects for future aesthetic content that may occur. Beijing's historical status determines that it has rich cultural connotations and unique research value. Beijing aesthetic culture research in the 20th century filled the blank of the modern part of the development of aesthetic culture in Beijing. It is one of the important means to establish "humanistic Beijing", carry out cultural innovation, protect the ancient capital's appearance, treasure the cultural heritage and finally realize the "Chinese Dream". The aesthetic activities involved are in Beijing or have a direct relationship with Beijing. In addition to the historical figures that grew up and settled in Beijing, there are many literati and artists who have temporarily lived or visited Beijing in the modern times. Their works are related to their lives in Beijing. The foreign culture and aesthetic concepts that affected Beijing's development should also be included in the research scope of modern Beijing aesthetic culture.

\section{The MACRo ReSEARCH OF BeIJING AESTHETIC CULTURE}

In many books on the study of Beijing culture, the research involving aesthetic culture can be divided into two major categories. The first category is tracing the origin in which it summarizes the aesthetic features of Beijing culture from the perspective of historical development. In this kind of research, the first step is to summarize the development characteristics of Beijing's aesthetic culture and the academic achievements of aesthetic laws directly from the origin of Beijing culture. The academic works represented by The History of Aesthetic Culture in Beijing (from ancient times to Yuan, Ming and Qing dynasty) were based on the laws of ancient aesthetic culture development in the Beijing area, and the "trilateral framework" and "three-point rotation" theory emerged from this, which provided a reference system for the follow-up Beijing aesthetic culture research. The "trilateral framework" of aesthetic culture in Beijing refers to the interactive relationship formed by three major prehistoric cultures of Central China Huaxia, Haiyi Dongyi and wesern Liaoning Beidi with Beijing as the center, that is the cultural aesthetic orientation, aesthetic details and potential of the three major cultures representing mountain roses, sunbirds and jadedragons collided and integrated in Beijing. The "threepoint rotation" of aesthetic culture in Beijing refers to the fact that one of the three major cultures occupies a dominant position during a certain period or historical period, while the other two cultures are in a passive subordinate position. The first rotation in the East, centering on Haidai Dongyi's culture, took place mainly in the Xia and Shang dynasties. Beijing's aesthetic culture originated from the south of Yanshan Mountain and ran to the south along the east of Taihang Mountainand took part in the creation of the bronze art of witch history; The second rotation of the west, centering on the Huaxia culture in Central Plains, occurred mainly in the West Zhou Dynasty and East Zhou Dynasty. Beijing's aesthetic culture crossed the Yanshan Mountain and reached the Liaohe River basin in the north and participated in the creation of the 
beauty of the poetry and music festival. The third rotations of the north with the focus on the Beidi culture in west Liaoning mainly occurred after the Qin and Han dynasties. Beijing's aesthetic culture completed its full integration of Chinese aesthetic culture in the ancient historical period under the combined forces of north and south. Since then, the aesthetic culture of Beijing in the Ming Dynasty was still in the process of the three-point rotation of the "three cultures" in the north and south, that is, during the process of cultural exchanges and integration of Huaxia Han culture and Beidi culture, its aesthetic features were mainly expressed as the "Youyan culture" into "Beijingization". Beijing in the Qing Dynasty was at the core of the multi-cultural rotation. Its aesthetic culture was mainly manifested in the aesthetic culture of the Manchu nobles centering on the imperial power, the scholars' aesthetic culture centering on the Han civil officials and the Keju scholars, and the popular aesthetic culture centering on citizen.

Secondly, some academic research summarizes the unique charm and development of contemporary Beijing culture from a macro perspective. This kind of research takes the modern and contemporary history of Beijing as a starting point and summarizes the aesthetic changes and aesthetic trends of modern and contemporary Beijing culture. In the content of the research, emphasis is placed on the transformation of traditional culture, the formation of consumerism and the coexistence of contemporary cultural patterns. The Thirty Years of Aesthetic Culture in Beijing by the Associate Professor Qin Yong from the School of Literature of the Capital Normal University contends that Beijing's aesthetic culture has undergone three transmutations in diachronicity, the aesthetic transformation of traditional culture to new culture, the formation of consumerism aesthetic culture under the impact of immigration culture, and the formation of a worldwide aesthetic cultural trends along with the positioning of the world's city; At present, Beijing's aesthetic culture has led some new trends and new changes in the country, such as the daily life of aesthetic culture, the scale of the aesthetic cultural industry and the informatization of aesthetic culture network and so on. In this transformation, it is expressed as the Beijing spirit of innovation and tolerance. Prof. Liu Yong observed the historical connotation, realistic condition and development trends of Beijing culture and believed that the characteristics of Beijing culture are uniqueness and representativeness, cohesiveness and assimilation, stability and development. The Uniqueness and Representation of Beijing Culture main present that Beijing culture on the one hand is a living art that permeates the sense of hedonism, and on the other hand, it has a strong sense of orthodoxy. The native Beijinger in the city was happy, humorous, generous, selfesteem and leisurely. They carry cages for birds, drink tea, chat and do cricket fighting. Their lifestyle and leisure time vividly illustrate the whole set of cultural concepts and cultural ideals bred by the ancient capital. Beijing culture also represents the spirit of traditional Chinese culture. A culture bases on morality, human decency and culture, and contains human dignity, human warmth and Chinese people's unique lifestyles, representing traditional Chinese ideals and hopes. The cohesion and assimilation of Beijing's culture refer that Beijing uses its value orientation of humanism and the rich historical culture to attract and cultivate people of all kinds, and integrate the culture of different forms. Han nationality has coexisted with 55 ethnic minorities living together, and people of different religious beliefs coexist in peace. People from different countries and regions in the world go forward hand in hand, and finally made the cultural patterns of multicultural coexistence and a combination of Chinese culture with the West culture in Beijing. In addition, Mr. Xu Daling's Talking about the Three Characteristics of Beijing Culture and Mr. Zhang Liwen's Talking about the Characteristics of Beijing Culture also used a macroscopic perspective to summarize Beijing culture. Mr. Xu believes that the characteristics of Beijing culture should be summarized as long-time culture, feudal culture and Beijing's new culture; Mr. Zhang placed Beijing culture in Chinese traditional culture. The characteristics of Beijing culture are summarized as longlasting, honest and conservative, and all these three characteristics have the duality of essence and dross. Prof. Qiu Yunhua's Study on the Formation and Discourse of Modern Culture in Beijing - The Significance of the Cultural History of the Late Qing Dynasty and the Early Republic of China (18981936) clearly clarified the occurrence of the modern form of Beijing culture and provided a reference for the origin of Beijing aesthetic culture in the 20th century. According to the article, it mainly emphasizes the end of the Qing Dynasty and the early years of the Republic of China, and the later year of 1936, the contemporary transformation of Beijing culture under the background of great changes in politics, history, economy and culture. He thought that the modern form of Beijing culture in the 20th century began in the 1900s; The premise of the modernity of Beijing culture from October 1949 is not the court culture in the Late Qing Dynasty before 1900, but is a brand new Beijing culture with new social and political content, ideological connotation, modern forms and life practices, and considered that this modern form is the bridge connecting the autocratic culture of the new China and the feudal.

Thirdly, some academic research divides Beijing culture into big culture and small culture. The content of big culture includes almost everything. Small culture refers specifically to the theatrical performances, cultural relic protection and news publishing under the guidance of the Beijing Municipal Publicity System. Mr. Li Jianping's Characteristics of Beijing Culture - Concurrently Discussing Beijing Culture and Beijing Study incorporated big culture into the research of Beijing Study. The research of Beijing aesthetic culture is decentralized into the sub-systems of regional culture, urban culture, metropolitan culture and kind capital culture. Although this kind of research does not systematically explain Beijing's aesthetic culture, each aspect involves the aesthetic features of Beijing culture. It includes the process of the origin, formation, development, and transfer of city sites in Beijing, as well as Beijing's cultural characteristics, customs and social life in different eras. In addition, the older generation of "Beijing study" scholars represented by Mr. Hou Renzhi often stalks the contents of Beijing aesthetic culture from a historical perspective. Among them, Mr. Hou's monograph of Lifemark of Beijing City starts from the river and Lake water system and geographical environment, and systematically reveals the process of origin, formation, development, and transfer of city 
sites in Beijing. The book describes in the modern times, Beijing's urban space expansion centered on Tiananmen Square, the old city as a pattern, a circular expansion and faces the reality of the urban upheaval in Beijing, taking it as a whole, and the vertical equilibrium is divided into west, east and middle parts. 18 regions were selected for observation and the internal logic of the regional space was analyzed, suggesting the unique charm of the Beijing urban space. Both Mr. Zhang Renzhong's History of Beijing from Peking University and Mr. Cao Zixi's General History of Beijing from the Beijing Academy of Social Sciences use time as sequence. They have made a concise, refined and clear introduction of the historical changes of the Shang Dynasty and the contemporary Beijing city. From the perspective of history, they examined the changes that Beijing had made in the planning and construction of cities for thousands of years, and paid attention to the fate of historical sites in ancient times.

\section{The Microscopic RESEARCH OF BeIJING AESTHETIC CULTURE}

The second kind of research work examines the prominent cultural phenomenon and social causes in contemporary Beijing culture from a microscopic point of view. This kind of research work mainly observes Beijing culture from two aspects. First, through the investigation of urban changes, the complex relationship between tradition and modernity is sought. Although there is no direct discussion about the development and changes of Beijing's aesthetic culture, in the argumentation, the folk culture's "traditional recovery" is fully demonstrated. American scholar Dong Ye used three chapters to describe the cultural expressions of Beijing in her book -Beijing City in the Republic of China: History and Nostalgia which is for the research of Beijing's urban transformation. She conducted a detailed analysis of sociological studies on Beijing in the Republic of China and different expressions of Beijing City by scholars of new and old generations. On the one hand, her research summarized the main contribution and the one-sidedness of the sociologists represented by Gamble on the study of the Beijing City in the Republic of China; on the other hand, it also affirmed the written expression as one of the categories of the aesthetic culture for urban locality and uniqueness. Second, by examining the daily life of ordinary citizens, it reveals the material life and spiritual life of Beijing natives. The research focused on Beijing civilians. The object was changed into ordinary citizens and the urban poor, and it interpreted their daily life horizontally. Such research not only reflected the influence of different governments and political policies on the lifestyle of Beijing natives, but also reflected the creation and consumption of aesthetic culture by the citizen class. The American scholar Chen Yijun's Guilty of Indigence: The Urban Poor in China 1900-1953 explains the meaning of poverty in different periods and restores readers to the different faces of the poor criminals in the city since China's modern life, while taking Beijing and Shanghai as examples, enriched the horizontal interpretation of the "poor people". In discussing the poor in Beijing, the book addresses different social and economic policies adopted by different governments for the poor in Beijing and uncovers social issues and believes that the emergence of the poor in Beijing is mainly due to political factors. The decline in the satisfaction class is a major part of the poor people in modern Beijing. Many of them prefer to suffer from hunger and starvation rather than to make a living in society. This kind of unearned life further affects the relationship between Manchu and Han. In addition, the loss of the status of the capital is also the cause of the gradual decline of Beijing and the accumulation of the poor. The Englishman Yan Ruibo's Life in Beijing is an English book that appeared in the 1920s to 1930s to study Beijing's social life and customs The author collected materials from various social strata, streetscapes and customs in Beijing, named Beijing as a city of pleasure, and collected more than one hundred pictures of the folk customs of Beijing at the time. His research results have provided reference resources for understanding all aspects of Beijing's life in the Republic of China.

The American woman anthropologist Ruth Benedict said in the Model of Culture: "A culture is like a person. It is a more or less consistent pattern of thought and behavior. Every culture will form a unique intent that does not necessarily have to be in other social forms." She believes that the "cultural model" includes three basic meanings: i. It is an integral whole and a system; ii. The integral whole has its own purport, namely the core value orientation and spiritual goal, which distinguishes itself from other systems; iii. There are systematic links between cultural traits around the core. In the process of summarizing the history of modern Beijing aesthetic culture, the three cultures influencing the aesthetic culture of Beijing worth emphasizing are Japanese culture, European and American culture and Russian culture. Among them, the influence of Japanese culture on Beijing culture is mainly concentrated in the eight years that Beijing became an enemy-occupied area and the contemporary youth subculture. European and American cultures have a profound influence on Chinese culture, especially Beijing culture, in terms of diet, way of thinking, attitude toward life, celebration of festivals and religious beliefs. In terms of diet, the integration of Western fast food culture and native tastes has formed a unique cultural scene. In the way of thinking, European and American democratic consciousness has far-reaching influence on China; in terms of life attitude, Confucian culture and European and American cultures have enjoyed joint development in seeking common ground while reserving differences; In the celebration of festivals and religious beliefs, although not everyone in China believes in Christianity, but they celebrate Valentine's Day, Christmas, etc. like the European and American people do, which also reflects the era of globalization, consumer culture in China. Russian culture, especially Russian literature, has long been accepted in China. It can still find traces left in the field of contemporary aesthetic culture in Beijing. Mr. Qian Gurong once said that Russian literature is just like milk, which makes him grow; to a certain extent, the influence of Russian literature on me has been not only limited to the literary level, it has penetrated into my soul, my blood, my bone marrow and my heart. For another example, Wang Meng, a famous writer in China, once wrote in his work that my way to writing was inspired by the work of Talking about writers by Ehrenburg. My short stories were influenced by First Job and The Oak in Winter and the ability to fully unearth the beauty of the spiritual world brought about by the new life was helped by Fadeyev. Therefore, we can say that Chinese writers and Russian writers share the same mind. 
Chinese writers have a special emotional recognition for Russian literature. Of course, in addition to literature, Russia's opera, ballet, architectural and other artistic theories and practices have also exerted a major influence on Beijing's aesthetic culture after liberation.

\section{CONCLUSION}

These research works have provided a comprehensive interpretation of all aspects of modern Beijing culture from a diachronic and consensus perspective. However, observing the development of Beijing culture from the aesthetic perspective is slightly inadequate. Aesthetics is based on people's emotional experience. To sum up the aesthetic transformation and aesthetic imagination of an era, we need to study the outstanding aesthetic events of the era, besides we should also place these aesthetic events in the background and culture system at that time for detailed investigation and research.

\section{REFERENCES}

[1] Chief Editor of Zou Hua: The History of Aesthetic Culture in Beijing (ancient times, Ming and Qing dynasty), Beijing: Peking University Press, 2013; 邹华主编: 《北京审美文化史》（上古、明、清 卷)，北京：北京大学出版社，2013 年;

[2] Hou Renzhi: The Origin and Change of Beijing City, Beijing: Yanshan Press, 1997; 侯仁之: 《北京城的起源与变迁》, 北京: 燕山出版 社, 1997 年;

[3] Chen Ping and Wang Dewei: Beijing: Urban Imagination and Cultural Study, Beijing: Peking University Press, 2005; 陈平原、王德威编: 《北京：都市想象与文化研究》，北京：北京大学出版社, 2005 年;

[4] Xu Huiqi: A New Look of the Capital: Social Consumption in Beiping 1928-1937, Taipei: Taiwan Student Book Company Limited, 2008; 许 慧琦: 《故都新貌：迁都后到抗战前的北平都市消费 19281937》, 台北: 台湾学生书局有限公司, 2008 年;

[5] [United States] Sidney. D. Gamble: The Social Survey of Beijing, translated by Chen Yubing, Yuan Jia, Qi Dazhi, Li Zuoqin, Ju Fang'an and Zhao Man, Beijing: China Bookstore, 2010; [美]西德尼 . D · 甘 博: 《北京的社会调查》, 陈愉秉 袁嘉 齐大芝 李作钦 鞠方安 赵 漫译, 北京: 中国书店, 2010 年;

[6] [United States] Dong Yue: Beijing City in the Republic of China: History and Nostalgia, Beijing: Sanlian Bookstore, 2014; [美]董玥: 《民国北京城: 历史与怀旧》, 北京: 三联书店, 2014 年;

[7] [USA] Ruth Benedict: Model of Culture, translated by He Xizhang and Huang Huan, Beijing: Huaxia Press, 1987 [美]露丝・本尼迪克: 《文 化模式》, 何锡章, 黄欢译, 北京: 华夏出版社, 1987 年 